\title{
Lecania cuprea and Micarea pycnidiophora (lichenized Ascomycota) new to Poland
}

\author{
Paweł Czarnota* \\ Department of Agroecology, University of Rzeszów, Ćwiklińskiej 2, 35-601 Rzeszów, Poland
}

\begin{abstract}
Two lichenized fungi, Lecania cuprea and Micarea pycnidiophora, are reported for the first time from Poland. Lecania cuprea is also recorded as a new lichen species to the Western Beskidy Mts and the Pieniny Mts and M. pycnidiophora is new to the Carpathians. Illustrated descriptions, taxonomic notes, habitat requirements and known distributions for both species are provided.
\end{abstract}

Keywords: lichens; calciphilous lichens; old-growth forest lichens; Polish Carpathians

\section{Introduction}

Recent lichenological exploration by the author in the Polish Western Carpathians has significantly extended our knowledge of lichen diversity in this mountainous area. Many species unrecorded to date in Poland in this region have already been reported (e.g. [1-10]), but data on several others have yet to be published; details of two such species, Lecania cuprea and Micarea pycnidiophora, collected in 2004 and 2014 are presented here. M. pycnidiophora, previously known only in Central Europe from České Švýcarsko (= the Bohemian Switzerland) in western part of the Czech Republic, is also reported for the Carpathians.

\section{Material and methods}

Specimens were determined by standard microscopy and simple spot test reactions. Hand-made apothecial and thallus sections mounted in water were used to measure all anatomical characters. In the case of Lecania cuprea, $\mathrm{KOH}$ was used to study its apothecial pigmentation.

Specimens have been deposited in the Herbarium of Gorce National Park (GPN). Nomenclature and synonyms of the presented taxa follow MycoBank (http://www.mycobank.org). Localities are mapped (Fig. 1) according to the Polish Atpol grid square system [11] modified for lichens by Cieśliński and Fałtynowicz [12]. Brief descriptions of diagnostic characters are based on Polish collections.

\footnotetext{
*Email: pawczarnota@poczta.onet.pl
}

Handling Editor: Beata Zagórska-Marek

\section{Results and discussion}

Lecania cuprea (A. Massal.) v.d. Boom \& Coppins

Nova Hedwigia 54(1-2): 234. 1992. E Bilimbia cuprea A. Massal., Lotos Prague 6: 77. 1856. $\equiv$ Bacidia cuprea (A. Massal.) Lettau, Hedwigia 52: 132. 1912.

\section{Diagnostic characters}

Thallus pale greyish-green to green, effuse, rimose to irregularly granular-warted, thin (Fig. 2a-d). Apothecia lecideoid, beige to orange-brown, simple or clustered in small groups, $0.3-0.7 \mathrm{~mm}$ in diam., sessile, plane to convex, at the beginning distinctly marginate, later often immarginate; thallus margin excluded and proper margin usually darker than the disc especially when moist. Apothecial section colorless except for pinkish-brown, $\mathrm{K}+$ pink to purplish, upper part of excipulum and epithecium (in darker apothecia). Ascospores $12-26 \times 2-3.5 \mu \mathrm{m}$, narrowly fusiform or baciliform, (1-)3(-5)-septate. For further details see descriptions by van den Boom [13] and Fletcher et al. [14].

\section{Notes}

Lecania cuprea markedly differs in phenotypic characters from the type species for the genus, L. cyrtella (Ach.) Th. Fr. It has no thalline margin, and its ascospores are narrowly fusiform and 3(-5)-septate while L. cyrtella has a distinct amphithecium in young development stage of ascocarps and 1-septate, narrowly ellipsoid ascospores. These characters and a distinct proper margin, which is usually darker colored than the disc (see Fig. 2a), as well as entirely \pm stout excipular hyphae make this species similar to representatives of the genera Bacidia De Not. or Bilimbia De Not. However, phylogenetic relationships of $L$. cuprea have not been confirmed to date. 


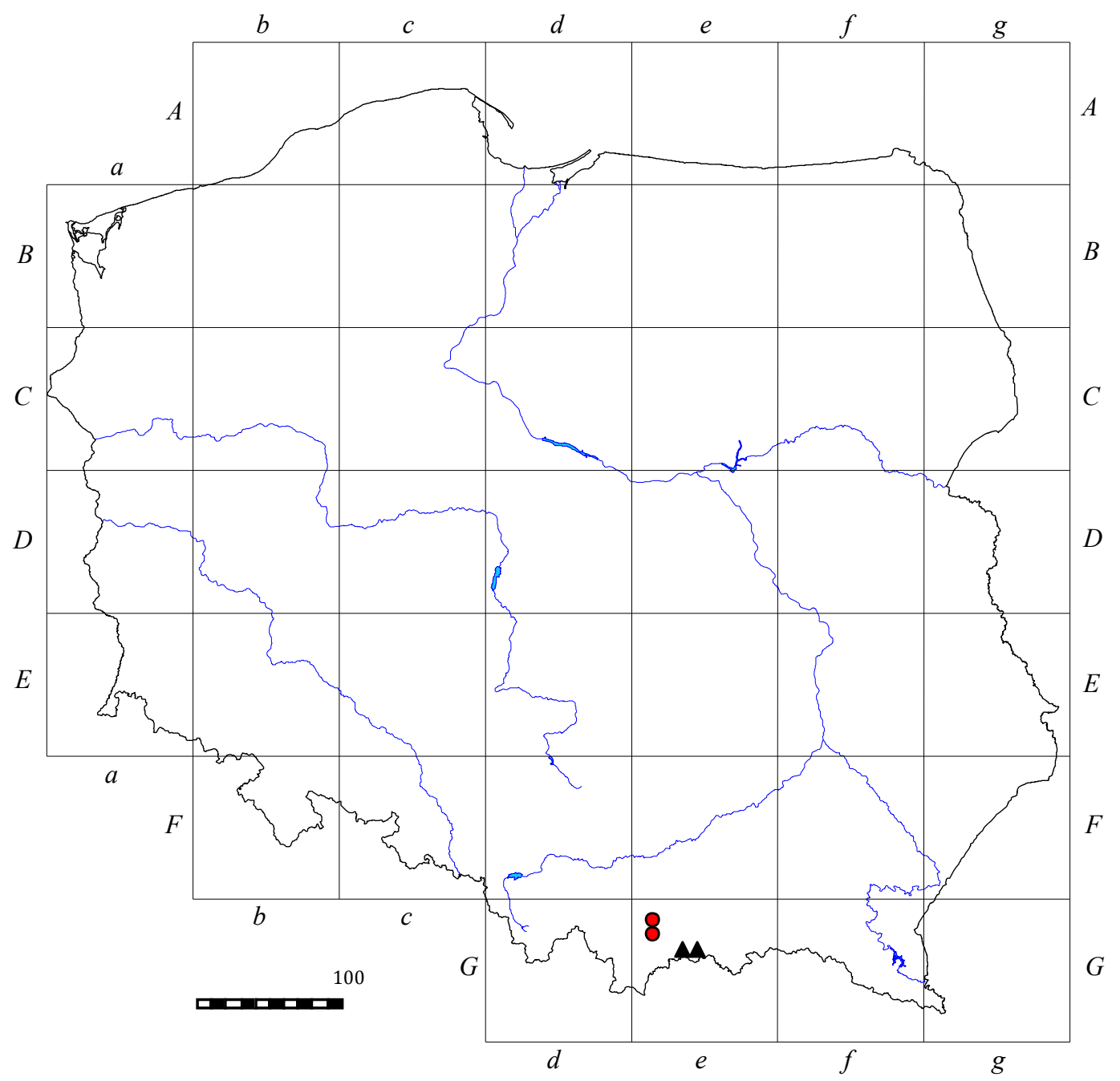

Fig. 1 Localities of Lecania cuprea (triangle) and Micarea pycnidiophora (circle) in Poland.

According to Fletcher et al. [14], the lumina of excipular fungal cells widen towards the outer edge of the proper margin. However, in Polish collections apices of the hyphae are not distinctly wider but the whole excipulum is made of \pm stout hyphae up to $2-3 \mu \mathrm{m}$ wide.

An epibryophytic pale coloured form of Lecania cuprea (Fig. 2b) morphologically resembles Bacidina delicata (Larbal. ex Leight.) V. Wirth \& Vězda and "Bacidia" pycnidiata Czarnota \& Coppins, other microlichens inhabiting bryophytes. From these two species L. cuprea differs in narrowly fusiform ascospores, the structure of non-granular thallus, and the excipular $\mathrm{K}+$ purplish pigmentation. The ascospores of Bacidina species and "Bacidia" pycnidiata are needle-like, their thallus is granular and they have no internal excipular pigmentation at all.

\section{Distribution and habitat requirements}

Generally, Lecania cuprea is rarely reported throughout Europe from the British Isles up to northern and central parts of European Russia (e.g. [14-23]). However, it is frequently found regionally in areas of calcareous rocks. In central Europe it is scarcely reported, e.g. from the Bavarian Forest [24] and the Czech Republic [25]. Close to Poland it has been recorded in the Slovak Tatra Mts [26] and Ukrainian Carpathians [27], but in both instances many years ago. Localities of L. cuprea are also known outside Europe, in the Azores [14], North America [28-30] and southern Siberia [23].

Lecania cuprea is a calciphilous species usually growing on under-hangs or vertical rock surfaces in woodlands, sometimes over-growing epilithic mosses, but its most recent Lithuanian collection was on a siliceous boulder influenced by a basic stream water [24].

The Polish records are the first for the Western Beskidy Mts (including Czech and Slovak part of the flysch Carpathians) and the calcareous Pieniny Mts (including Slovak part).

\section{Specimens examined}

Poland, Carpathians: Atpol Ge-33, Pieniny National Park, forest section No. 7, valley of Ociemny stream, $49^{\circ} 25^{\prime} 46^{\prime \prime}$ $\mathrm{N}, 20^{\circ} 25^{\prime} 41^{\prime \prime} \mathrm{E}$, alt. ca. $600 \mathrm{~m}$, on limestone and saxicolous bryophytes, 13.05.2004, leg. P. Czarnota 3845 (GPN); Atpol Ge-34, Beskid Sądecki Mts, Radziejowa range, close to "Baniska” Nature Reserve, 49 26'48" N, 20³6'39" E, alt. ca. $1060 \mathrm{~m}$, on calcareous sandstone rocks, 4.11.2004, leg. P. Czarnota 4377 (GPN). 

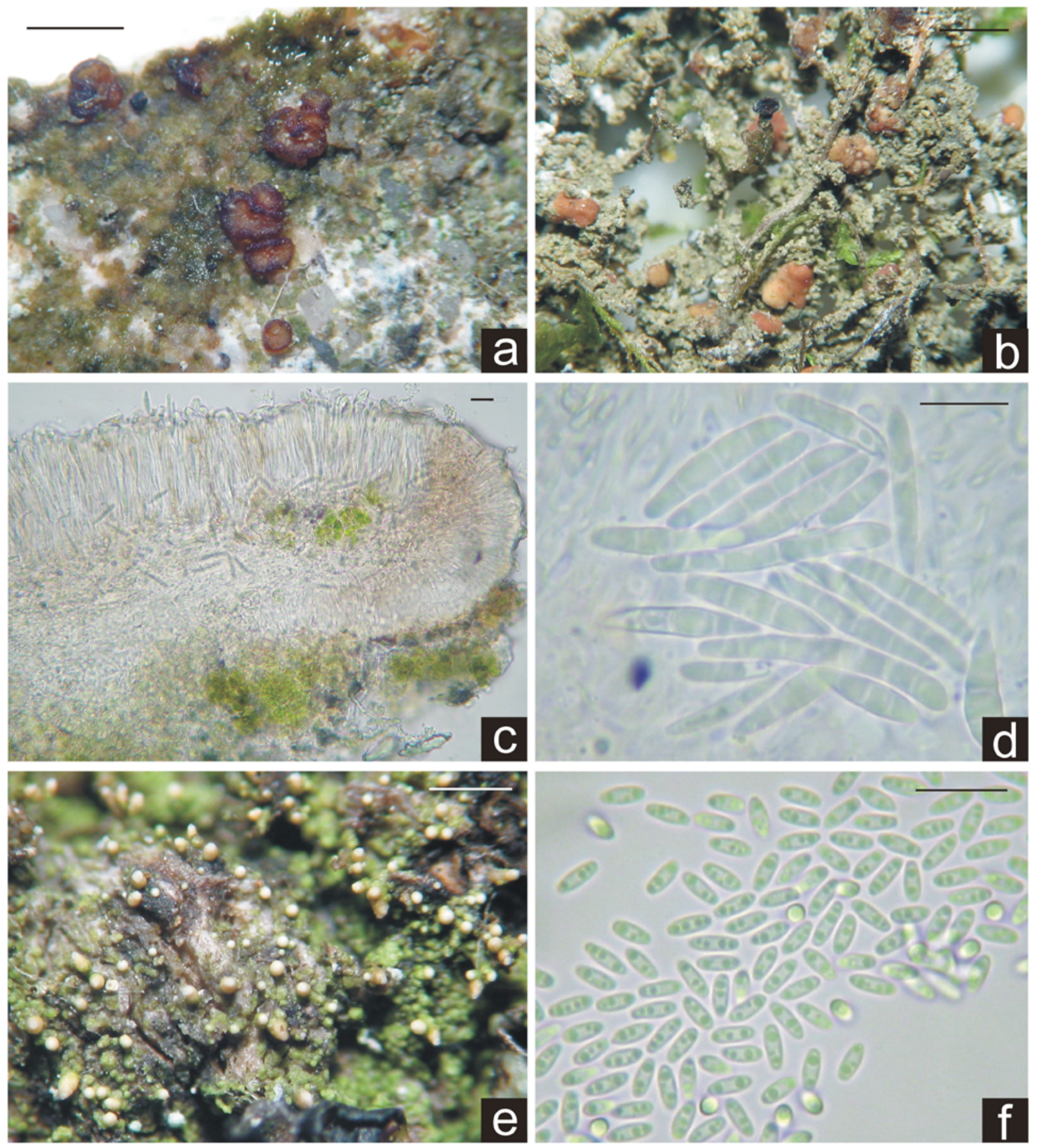

Fig. 2 Characteristics of Polish collections of Lecania cuprea (a-d) and Micarea pycnidiophora (e-f). Lecania cuprea: (a) habit of waterlogged saxicolous specimen (P. Czarnota 4377); (b) habit of epibryophytic specimen overgrowing limestone rock (P. Czarnota 3845), (c) apothecial section in water and (d) ascospores. Micarea pycnidiophora: (e) habit and (f) conidia. Scale bars: a,b,e $1 \mathrm{~mm} ; \mathbf{c}, \mathbf{d}, \mathbf{f} 10 \mu \mathrm{m}$.

\section{Micarea pycnidiophora Coppins \& P. James}

Lichenologist 11: 153 (1979).

\section{Diagnostic characters}

Thallus green, uneven, finely warted, sometimes indistinct (Fig. 2e-f). Photobiont micareoid, 5-7 $\mu \mathrm{m}$ in diam. Pycnidia white to cream-colored, numerous, sessile to stalked, $\mathrm{C}+$ red due to gyrophoric acid. Conidia bacilliform to ellipsoid, 4-6 $\times 1-1.5 \mu \mathrm{m}$. Apothecia not seen in Polish collections. For more details, especially apothecial characters, see Coppins [31].

\section{Notes}

In its morphology and anatomy, M. pycnidiophora most closely resembles M. stipitata Coppins \& P. James and M. neostipitata Coppins \& May, by forming stipitate, pale pycnidia and immarginate apothecia. Main differences between these three species are in their chemistry: $M$. $p y c-$ nidiophora produces gyrophoric acid with $\mathrm{C}+$ red reaction of pycnidia, thallus and apothecia, while M. stipitata has no lichen secondary compounds and M. neostipitata, to date found only in North America, produces fumarprotocetraric and lobaric acids and contains $\mathrm{K}+$ violet Sedifolia-grey 
pigment in its apothecial and pycnidial sections [32]. Differences in dimensions of their conidia are also emphasized, but they are not so distinct in $M$. pycnidiophora and M. neostipitata; 3.8-6× 1-1.5 $\mu \mathrm{m}$ vs. 3.8-4.8 × 1-1.5 $\mu \mathrm{m}$ [32].

\section{Distribution and habitat requirements}

Micarea pycnidiophora is a corticolous species very rarely reported from both sides of the northern Atlantic. It has been recorded in Britain, France and the Canary Islands [31], Belgium and Luxembourg [16,33], NW Spain [34] and south-eastern USA [32]. Recently it has also been discovered in the Czech Republic [35] and the Leningrad region in Russia [36], as well as in the Himalayas [37]. The records presented here are new to Poland and the Carpathians. Except for Russia, where M. pycnidiophora was collected for the first time on conifers (Picea), it is found on old deciduous trees (Fagus, Acer, Alnus, Quercus) or shrubs (e.g. Ilex, Rhododendron) [34,38].

The British population of M. pycnidiophora is said to be the richest in the World [39], but concentrated occurrences of this species on the European continent have also been found in the Ardennes Forest, in Belgium and Luxembourg [16]. These occurrences and the North American range of

\section{Acknowledgments}

I am thankful to the reviewers and editor for all suggestions and language corrections improving the final work. This research was partially supported by the University of Rzeszów task grant No. WBR/KA/DS/5/2014. Field studies were supported by the Gorce National Park within the project POIS.05.03.00-00-273/10 and by the General Inspection for Environmental Protection within the project "Monitoring of forest phytocenosis 2002-2004" realized by Forest Research Institute, Department of Mountain Forests in Kraków.

\section{Competing interests}

No competing interests have been declared.

\section{References}

1. Czarnota P, Coppins BJ. A new Bacidia with long-necked pycnidia from Central Europe. Lichenologist. 2006;38:407-410. http://dx.doi. org/10.1017/S0024282906005986

2. Kukwa M, Czarnota P. New or interesting records of lichenicolous fungi from Poland IV. Herzogia. 2006;19:111-123.

3. Czarnota P, Coppins BJ. Contribution to the knowledge of rare Bacidia s.lat. (Lecanorales, lichenized Ascomycetes) from Central Europe including a new, pallid forma of Bacidia hemipolia. Nova Hedwigia. 2007;85:503-513. http://dx.doi. org/10.1127/0029-5035/2007/0085-0503

4. Czarnota P. The lichen genus Micarea (Lecanorales, Ascomycota) in Poland. Pol Bot Stud. 2007;23:1-199.

5. Czarnota P, Flakus A, Printzen C. Lecanora flavoleprosa (Lecanoraceae, lichenized Ascomycota) found in the Carpathians. Biologia. 2009;64:1066-1069. http://dx.doi.org/10.2478/s11756-009-0180-x

6. Czarnota P. Japewia tornoensis and further localities of J. subaurifera found in the Carpathians. Acta Mycol. 2009;44:259-264. http://dx.doi. org/10.5586/am.2009.024

7. Czarnota P, Osyczka P, Kowalewska A. Status of some poorly known lichen species from the genus Lecanora (lichenized Ascomycota) in Poland. Mycotaxon. 2010;113:449-462. http://dx.doi.org/10.5248/113.449

8. Kukwa M, Czarnota P, Perz P. New or interesting records of lichenicolous fungi from Poland VIII. Herzogia. 2010;23:111-119. http://dx.doi. org/10.13158/heia.23.1.2010.111
M. pycnidiophora could suggest that this species belongs to a subatlantic element in the lichen biota. In the light of this, both known Central European populations of this lichen in the Czech Republic and Poland (and indeed the Himalayas) appear to be isolated. Palice et al. [35] suggest that this species may represent a relic of formerly much richer epiphytic lichen biota as it was found in association with other lichen peculiarities. In the Polish Carpathians, M. pycnidiophora was associated with several old-growth forest lichens such as Loxospora elatina, Ochrolechia androgyna, Thelotrema lepadinum and Usnea spp., growing within one of the best preserved spruce-fir-beech forest in the Western Carpathians.

\section{Specimens examined}

Poland, Carpathians, Gorce range, Gorce National Park: Atpol Ge-11, valley of the Gorcowy stream, forest section No. 80, 49 $34^{\prime} 58.84^{\prime \prime} \mathrm{N}, 20^{\circ} 11^{\prime} 55.9^{\prime \prime} \mathrm{E}$, alt. $950 \mathrm{~m}$, on bark of Fagus sylvatica, 30.04.2014, leg. P. Czarnota 7597 (GPN); Atpol Ge-21, valley of the Kamienica stream, forest section No. 95, 49³3'41.7" N, 20²' $03.8^{\prime \prime}$ E, alt. $860 \mathrm{~m}$, on bark of old Fagus sylvatica, 27.01.2014, leg. P. Czarnota 7557 (GPN).

9. Czarnota P. Micarea contexta and M. lynceola (lichenized Ascomycota), new for Poland. Pol Bot J. 2011;56:307-313.

10. Czarnota P, Hernik E. Mniaecia jungermaniae and Puttea margaritella (lichenized Ascomycota) found in Poland. Acta Soc Bot Pol. 2013;82:175-179. http://dx.doi.org/10.5586/asbp.2013.014

11. Zając A. Atlas of distribution of vascular plants in Poland (ATPOL). Taxon. 1978;27(5-6):481-484. http://dx.doi.org/10.2307/1219899

12. Cieśliński S, Fałtynowicz W, editors. Note from editors. In: Atlas of the geographical distribution of lichens in Poland. Kraków: W. Szafer Institute of Botany, Polish Academy of Sciences; 1993. p. 7-8.

13. van den Boom PPG. The saxicolous species of the lichen genus Lecania in the Netherlands, Belgium and Luxemburg. Nova Hedwigia. 1992;54:229-254.

14. Fletcher A, James PW, Purvis OW. Lecania A. Massal. (1853). In: Smith CW, Aptroot A, Coppins BJ, Fletcher A, Gilbert OL, James PW, et al., editors. The lichens of Great Britain and Ireland. London: British Lichen Society; 2009. p. 454-463.

15. Aptroot A, van Herk CM, Sparrius LB, Spier JL. Checklist van de Nederlandse Korstmossen en korstmosparasieten. Buxbaumiella. 2004;69:17-55.

16. Diederich P, Ertz D, Stapper N, Sérusiaux E, van den Broeck D, van den Boom P, et al. The lichens and lichenicolous fungi of Belgium, Luxembourg and northern France [Internet]. 2014 [cited 2014 Jan 28]; Available form: http://www.lichenology.info

17. Ariño X, Gomez-Bolea A, Saiz-Jimenez C. Lichens on ancient mortars. Int Biodeterior Biodegradation. 1997;40:217-224. http://dx.doi. org/10.1016/S0964-8305(97)00036-X

18. Nimis PL. Martellos S. ITALIC - The Information System on Italian Lichens. Version 4.0 [Internet]. 2008 [cited 2015 Jun 3]; Available from: http://dbiodbs.univ.trieste.it

19. Scholz P. Katalog der Flechten und flechtenbewohnenden Pilze Deutschlands. Schriftenreihe Vegetationsk. 2000;31:1-298.

20. Santesson R, Moberg R, Nordin A, Tønsberg T, Vitikainen O. Lichenforming and lichenicolous fungi of Scandinavia. Uppsala: Museum of Evolution, Uppsala University; 2004.

21. Motiejūnaitė J, von Brackel W, Stončius D, Preikša Ž. Contribution to the Lithuanian flora of lichens and allied fungi. III. Bot Lith. 2011;17:39-46. 
22. Randlane T, Saag A, editors. Second checklist of lichenized, lichenicolous and allied fungi of Estonia. Folia Cryptogam Est.1999;35:1-132.

23. Urbanavichus G, Andreev M. A checklist of the lichen flora of Russia St. Petersburg: Nauka; 2010.

24. Kanz B, Dürhammer O, Printzen C. Lichens and lichenicolous fungi of the Bavarian Forest. Preslia. 2005;77:355-403.

25. Liška J, Palice Z, Slavíková Š. Checklist and red list of lichens of the Czech Republic. Preslia. 2008;80:151-182.

26. Lisická E. The Lichens of the Tatry Mountains. Bratislava: Veda; 2005.

27. Kondratyuk SY, Khodosovtsev A, Zelenko SD. The second checklist of lichen forming, lichenicolous and allied fungi of Ukraine. Kiev: Phytosociocentre; 1998.

28. Harris RC. A preliminary list of the lichens of New York. Opusc Philolichenum. 2004;1:55-74.

29. Nash III TH, Ryan BD, Diederich P, Gries C, Bugartz F, editors. Lichen flora of the greater Sonoran Desert region. Tempe, AZ: Lichens Unlimited, Arizona State University; 2004. (vol 2).

30. Hodkinson BP, Case MA. A lichen survey of Williamsburg, Virginia. Banisteria. 2008;31:24-30.

31. Coppins BJ. A taxonomic study of the lichen genus Micarea in Europe. Bull Br Mus. 1983;11(2):17-214
32. Coppins BJ, May PF. Micarea neostipitata, a new species with pale stipitate pycnidia from eastern North America. Lichenologist. 2001;33:487-490. http://dx.doi.org/10.1006/lich.2001.0350

33. Diederich P, van den Broeck D, Ertz D, Heylen O, Jordaens D, Sérusiaux E. Report on two lichenological field meetings in the province of Luxembourg in Belgium. Bull Soc Nat Luxemb. 2004;105:57-64.

34. Fernández Rodríguez R, Paz Bermúdez G, Carballal R. Los líquenes corticícolas del LIC Fraga de "A Marronda" (Galicia, NO de España). NACC Bioloxía. 2005;14:43-49.

35. Palice Z, Slavíková-Bayerová Š, Peksa O, Svoboda D, Kučerová L. The lichen flora of the Bohemian Switzerland National Park (Czech Republic). In: Härtel H, Cílek V, Herben T, Jackson A, Williams RB, editors. Sandstone landscapes. Praha: Academia; 2007. p. 200-204.

36. Kuznetsova ES, Motiejűnaitë J, Stepanchikova IS, Himelbrant DE, Czarnota P. New records of lichens and allied fungi from the Leningrad Region, Russia. III. Folia Cryptogam Est. 2012;49:31-37.

37. Aptroot A, Feijen FJ. Annotated checklist of the lichens and lichenicolous fungi of Bhutan. Fungal Divers. 2002;11:21-48.

38. Coppins BJ, James PW. New or interesting British lichens IV. Lichenologist. 1979;11:139-179. http://dx.doi.org/10.1017/S0024282979000190

39. Woods RG, Coppins BJ. A conservation evaluation of British lichens and lichenicolous fungi. Species status 13. Peterborough: Joint Nature Conservation Committee; 2012. 